\title{
PERANCANGAN ANTENA MONOPOL CETAK UNTUK KOMUNIKASI ULTRA WIDEBAND DENGAN ANALISIS MODE KARAKTERISTIK
}

\author{
Denti Agustina Damayanti*), Teguh Prakoso, dan Aghus Sofwan \\ Departemen Teknik Elektro, Universitas Diponegoro \\ Jl. Prof. Sudharto, SH, Kampus UNDIP Tembalang, Semarang 50275, Indonesia \\ ${ }^{*}$ E-mail: denti.agustina27@gmail.com
}

\begin{abstract}
Abstrak
UWB (Ultra Wideband) adalah sistem komunikasi jarak pendek yang mempunyai bandwidth yang sangat lebar beroperasi pada frekuensi 3,1-10,6 GHz. Dengan bandwidth operasi UWB yang besar maka diperlukan suatu antena dengan bandwidth yang besar pula, salah satu pendekatan untuk memperlebar bandwidth antena adalah dengan menggunakan Theory Characteristic Mode (TCM). Perancangan antena monopol cetak pada frekuensi kerja 3,1-10,6 GHz menggunakan bahan FR-4 dengan ketebalan 1,575 mm, dan konstanta dielektrik sebesar 4,3. Simulasi pancaran gelombang elektromagnetik menggunakan perangkat lunak CST Studio Suite 2016. Dari hasil simulasi, antena monopol cetak mempunyai bandwidth 8,4 GHz dengan rentang frekuensi 2,5-10,9 GHz. Pada hasil simulasi frekuensi $3,1 \mathrm{GHz}, 5 \mathrm{GHz}$, dan 10,6 GHz yang diperoleh nilai return loss kurang dari -10 dan VSWR sudah kurang dari 2, serta nilai gain lebih dari $2 \mathrm{~dB}$ dengan pola radisi omnidirectional. Hasil pengukuran antena monopol cetak mempunyai bandwidth 7,735 GHz dengan rentang frekuensi 3,18-10,915 GHz. Pada hasil pengukuran frekuensi 3,1 GHz, $5 \mathrm{GHz}$, dan 10,6 GHz yang diperoleh nilai return loss kurang dari -10 dan VSWR sudah kurang dari 2, serta nilai gain sebesar $3,27 \mathrm{~dB}$ dengan pola radisi omnidirectional. Antena tersebut telah memenuhi spesifikasi komunikasi ultra wideband.
\end{abstract}

Kata Kunci : Antena monopol cetak, UWB, Theory characteristic mode

\begin{abstract}
UWB (Ultrawideband) is a short-range communication system that has a very wide bandwidth operating at a frequency of 3.1-10.6 GHz. With a large UWB operating bandwidth, a large bandwidth antenna is required, one of the approaches to widen the antenna bandwidth is by using Characteristic Mode Analysis (CMA). The design of print monopoly antenna at working frequency $3,1-10,6 \mathrm{GHz}$ using material FR-4 with thickness $1,575 \mathrm{~mm}$, and dielectric constant equal to 4,3. Simulation of electromagnetic waves using CST Studio Suite 2016 software. From the simulation results, print monopoly antenna has a bandwidth of $8.4 \mathrm{GHz}$ with a frequency range of 2.5 to $10.9 \mathrm{GHz}$. In the simulation result of frequency of $3.1 \mathrm{GHz}, 5 \mathrm{GHz}$, and $10.6 \mathrm{GHz}$ obtained the return loss value less than -10 and VSWR is less than 2 , and the gain value more than $2 \mathrm{~dB}$ with omnidirectional radiation pattern. The result of measurement of print monopole antenna has bandwidth of $7.735 \mathrm{GHz}$ with frequency range 3,18-10,915 GHz. In the result of measurement frequency of $3.1 \mathrm{GHz}, 5 \mathrm{GHz}$, and $10.6 \mathrm{GHz}$ obtained by return loss value less than -10 and VSWR have less than 2 , and value of gain equal to $3,27 \mathrm{~dB}$ with omnidirectional radiation pattern. The antenna has met the ultrawideband communications specifications.
\end{abstract}

Keywords: Print monopole antenna, UWB, characteristic mode analysis

\section{Pendahuluan}

Teknologi radio ultra-wideband (UWB) adalah penemuan aplikasi dalam sistem komunikasi data nirkabel tingkat tinggi, yang digunakan untuk radio kognitif, radar, pencitraan biomedis, lokalisasi dalam ruangan, pelacakan dan lain-lain [1-2]. Meskipun pertimbangan desain antena biasanya ditentukan oleh aplikasi dan sistem pertimbangan tertentu, pada umumnya, antena monopol cetak berukuran kecil yang memiliki koefisien refleksi, gain, dan pola radiasi yang yang dapat menghasilkan bandwidth yang sangat lebar. Telah diketahui bahwa antena monopol cetak UWB menawarkan fitur menarik seperti bentuk yang sederhana dan bandwidth yang sangat lebar yaitu 3 sampai $10 \mathrm{GHz}$, ukuran yang kecil, dan kemudahan manufaktur [1-4].

Meskipun sejumlah antena monopol dicetak dengan kinerja yang optimal pada perancangan sebelumnya yang telah dipublikasikan, tetapi sangat sedikit jenis antena dengan analisis karakteristik perilaku fisik yang tersedia. Perilaku fisik pada antena dapat diketahui dengan Theory Characteristic Mode (TCM). TCM awalnya diusulkan oleh Garbacz [5] dan kemudian disempurnakan oleh 
Harrington [6] menganalisis perilaku antena untuk memberikan lebih banyak interpretasi fisik dari fenomena radiasi yang terjadi pada struktur. TCM juga telah berhasil digunakan untuk desain dan analisis berbagai antena kawat dan planar [7,8]. Dalam perancangan ini TCM digunakan untuk memberikan wawasan fisik ke dalam perilaku yang memancar dari antena monopol cetak ultra wideband.

Perancangan ini menggunakan monopol cetak dengan bevel dan upaya untuk merancang menggunakan teori mode karakteristik untuk mencapai operasi pada UWB yaitu frekuensi 3,1-10,6 GHz. Antena monopol cetak berbentuk bevel dianalisa kinerja eigen value, modal significance, dan characteristic angle dengan menggunakan teori mode karakteristik. Antena monopol cetak berbentuk bevel dirancang memiliki ukuran yang kecil yaitu $40 \times 45 \times 1,6 \mathrm{~mm}^{3}$ menggunakan bahan FR4 dengan ketebalan $1,6 \mathrm{~mm}$, dan konstanta dielektrik sebesar 4,3. Pola radiasi yang digunakan adalah pola radiasi omnidirectional. Metode yang digunakan pada perancangan antena ini yaitu dengan characteristic mode analysis (CMA) yang disimulasikan pada perangkat lunak CST Microwave Studio 2016 untuk mendapatkan desain terbaik berdasarkan frekuensi resonansi, Voltage Standing Wave Ratio (VSWR), return loss, gain, dan pola radiasi.

\section{Metode}

\subsection{Characteristic Mode Analysis (CMA)}

Characteristic mode adalah current mode yang nyata yang dapat dihitung secara numerik untuk menentukan bentuk dan sifat dielectric secara acak. Characteristic current modes $J_{n}$ dapat didefinisikan sebagai serangkaian arus nyata pada permukaan orthogonal tergantung bentuk objek dan ukuran. Total distribusi arus pada antena adalah superposisi dari characteristic mode dengan koefisien pembobotan yang tepat. Karena characteristic mode membentuk serangkaian fungsi orthogonal, maka dapat digunakan untuk memperluas arus total pada permukaan patch antena [9]. Menurut penelitian sebelumnya [9], hubungan mode dengan daya yaitu daya dapat dipancarkan oleh permukaan patch antena. Sedangkan characteristic current yaitu serangkaian characteristic fields $E_{n}$ yang dapat dihitung. Oleh karena itu, medan yang dipancarkan oleh antena dapat dinyatakan sebagai superposisi characteristic fields atau modal fields. Characteristic current modes dapat diperoleh dengan fungsi eigen hal ini karena pembobotan pada persamaan eigen value sebagai berikut :

$$
X\left(\vec{J}_{n}\right)=\lambda_{n} R\left(\vec{J}_{n}\right)
$$

Dimana $\lambda_{n}$ adalah eigen value, $\vec{J}_{n}$ adalah arus eigen, dan $\mathrm{R}$ dan $\mathrm{X}$ adalah bagian real dan imajiner dari matirks impedansi $\mathrm{Z}$ yang dihitung dengan memecahkan persamaan integral dengan menggunakan Method of
Moments (MoM). Setiap characteristic mode dikaitkan dengan eigen value, $\lambda_{n}$. Parameter ini memberikan pemahaman mengenai: magnitudo yang memberikan informasi tentang radiasi dari mode terkait dan daya reaktif dari mode yang sebanding dengan magnitudo pada eigen value. Dengan kata lain, pada mode tertentu eigen value dengan magnitudo yang kecil, dapat berkontribusi pada radiasi antena saat dieksitasi [8]. Eigen value akan memberikan kontribusi untuk menyimpan energi magnetik pada mode dengan $\lambda_{n}>0$ atau menyimpan energi listrik ketika mode dengan $\lambda_{n}<0$.

Kuantitas yang dikenal sebagai 'modal significance' $\left(M S_{n}\right)$ umumnya digunakan untuk karakterisasi antena dan menggambarkan amplitudo normal dari current mode.

$M S_{n}=\left|\frac{1}{1+j \lambda_{n}}\right|=\frac{1}{\sqrt{2}}=0,707$

$M S_{n}$ menentukan untuk berapa banyak jumlah mode yang berkontribusi terhadap radiasi. Resonansi untuk setiap mode terjadi secara ideal ketika $\lambda_{n}=0$ dimana pada saat itu modal significance berada pada nilai maksimum $\left(M S_{n}=1\right)$

\subsection{Spesifikasi Antena}

Antena yang dirancang adalah antena monopol cetak dengan spesifikasi:
a) Frekuensi kerja $3,1 \mathrm{GHz}-10,6 \mathrm{GHz}$
b) Nilai return loss $\leq-10 \mathrm{~dB}$ pada frekuensi kerja
c) Pola radiasi omdirectional
d) Gain > 2

\subsection{Dimensi Patch}

Antena yang dirancang adalah antena monopol cetak dengan frekuensi kerja $3,1 \mathrm{GHz}-10,6 \mathrm{GHz}$ dimana frekuensi tengahnya adalah $6,85 \mathrm{GHz}, \varepsilon_{r}=4,3$, dan $c=$ $3 \times 10^{8}$.

\subsubsection{Lebar patch $(\mathrm{W})$ :}

Untuk dapat menentukan lebar patch dari antena mikrostrip, dapat digunakan persamaan (3). [10]

$$
\begin{aligned}
& W=\frac{c}{2 f_{0} \sqrt{\frac{(\varepsilon r+1)}{2}}} \\
& W=\frac{3 \times 10^{8}}{2 \times 6,85 \times 10^{9} \sqrt{\frac{(4,3+1)}{2}}} \\
& W=0,01336 \mathrm{~m} \\
& W=\mathbf{1 3 , 3 6} \mathbf{~ m m} \\
& \text { 2.3.2 Panjang patch }(L)
\end{aligned}
$$

Untuk menentukan panjang (L) dari antena mikrostrip digunakan persamaan sebelumnya kita harus mengetahui 
nilai konstanta dielektrik efektif $\left(\varepsilon_{\text {reff }}\right)$ bahan substrat terlebih dahulu dengan menggunakan persamaan (4).

$\varepsilon_{\text {reff }}=\frac{\varepsilon_{r}+1}{2}+\frac{\varepsilon_{r}-1}{2}\left(1+12 \frac{h}{W}\right)^{-1 / 2}$

Maka:

$\varepsilon_{\text {reff }}=\frac{4,3+1}{2}+\frac{4,3-1}{2}\left(1+12 \frac{0,0016}{0,01336}\right)^{-1 / 2}=3,79$

Kemudian setelah konstanta dielektrik efektif $\left(\varepsilon_{\text {reff }}\right)$ diketahui, kita dapat menghitung pertambahan panjang akibat adanya fringing effect yaitu $\Delta \mathrm{L}$ yang dapat dihitung dengan persamaan $(5)$

$\Delta L=0,412 \times h \frac{\left(\varepsilon_{r e f f}+0,3\right)\left(\frac{W}{h}+0,264\right)}{\left(\varepsilon_{r e f f}-0,258\right)\left(\frac{W}{h}+0,8\right)}$

$h=0,0016 \mathrm{~m}=1,6 \mathrm{~mm}$

$\Delta L=0,412 \times 0,0016 \frac{(3,79+0,3)\left(\frac{00,01336}{0,0016}+0,264\right)}{(3,79-0,258)\left(\frac{0,01336}{0,0016}+0,8\right)}$

$\Delta \mathrm{L}=7,19 \times 10^{-4} \mathrm{~m}$

$\Delta \mathrm{L}=0,719 \mathrm{~mm}$

Dimana $\mathrm{h}$ merupakan tebal substrat kemudian panjang patch (L) dirumuskan pada persamaan (6).

$\mathrm{L}=L_{e f f}-2 \Delta L$

Dimana $L_{\text {eff }}$ merupakan panjang patch efektif yang dapat dirumuskan persamaan (7).

$L_{e f f}=\frac{c}{2 f_{0} \sqrt{\varepsilon_{\text {reff }}}}$

Maka:

$L_{e f f}=\frac{c}{2 f_{0} \sqrt{\varepsilon_{\text {reff }}}}=\frac{3.10^{8}}{2 \times 6.85 \times 10^{9} \sqrt{3,79}}$

$L_{\text {eff }}=0,01125 \mathrm{~m}$

$L_{\text {eff }}=11,25 \mathrm{~mm}$

Sehingga hasil panjang patchnya adalah :

$$
\begin{aligned}
\mathrm{L} & =0,01125-\left(2 \times 7,19 \times 10^{-4}\right) \\
& =0,02582 \mathrm{~m} \\
& =\mathbf{9 , 8 1 2} \mathbf{~ m m}
\end{aligned}
$$

\subsection{Desain Antena A (Ukuran Sesuai Perhitungan)}

\subsubsection{Desain Characteristic Mode Analysis Patch A}

Pada Gambar 1 menampilkan desain patch antena A pada characteristic mode analysis (CMA)

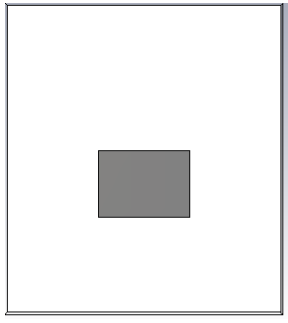

Gambar 1. Desain Patch A dengan CMA

Gambar 2 menampilkan hasil modal significant desain patch A dengan mode aktif $j_{n}$ dari antena A.

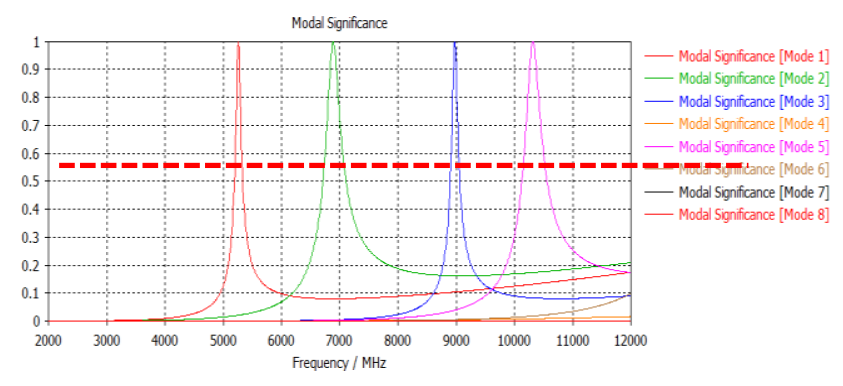

Gambar 2. Grafik Modal Significance patch A

Modal significance patch A, dari 8 mode yang diaktifkan hanya 4 mode saja yang mencapai nilai maksimum. Keempat mode yang mencapai nilai maksimum beresonansi dan didominasi radiasi dari frekuensi tinggi yaitu 5-10,5 $\mathrm{GHz}$ dan belum ada yang beresonansi pada frekuensi rendah seperti spesifikasi diharapkan yaitu 3,1 $\mathrm{GHz}$.

\subsubsection{Desain Antena A (Ukuran Sesuai Perhitungan)}

Hasil perhitungan dan perancangan antena ditunjukkan pada tabel 1, sehingga didapatkan desain simulasi awal seperti yang ditampilkan pada Gambar 3

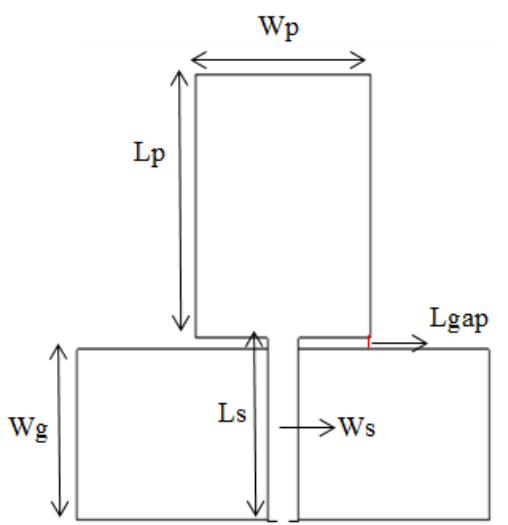

Gambar 3. Desain antena A untuk komunikasi UWB 
Tabel 1. Ukuran desain antena A untuk komunikasi UWB

\begin{tabular}{lcc}
\hline \multicolumn{1}{c}{ Nama } & Simbol & Value $(\mathbf{m m})$ \\
\hline Lebar patch & Wp & 13,4 \\
Panjang patch & $\mathrm{Lp}$ & 9,8 \\
Lebar ground & $\mathrm{Wg}$ & 13 \\
Lebar saluran & Ws & 3 \\
Panjang saluran & $\mathrm{Ls}$ & 13,9 \\
Sudut bevel & $\alpha$ & - \\
Gap & Lgap & 0,9 \\
\hline
\end{tabular}

\subsection{Hasil Simulasi Antena A}

\subsubsection{Return Loss}

Hasil return loss antena A dapat ditampilkan pada grafik yang terdapat pada Gambar 4

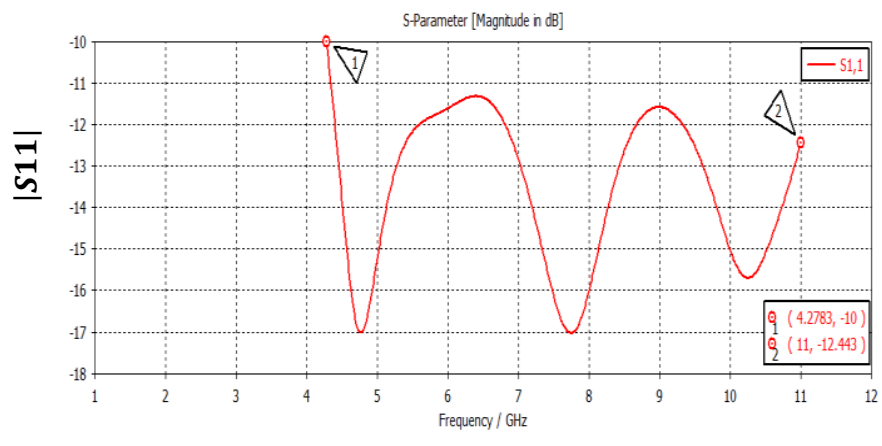

Gambar 4.Grafik Koefisien Refleksi $|S 11|$ Terhadap Frekuensi Desain Antena A

Berdasarkan grafik tersebut, terlihat bahwa frekuensi antena A adalah 4,3-11 GHz dimana hasil tersebut belum memenuhi frekuensi yang diharapkan spesifikasi yaitu $3,1-10,6 \mathrm{GHz}$

\subsubsection{Gain dan pola radiasi}

Hasil pola radiasi dan gain antena A pada frekuensi 3,1 $\mathrm{GHz}, 5 \mathrm{GHz}$, dan 10,6 GHz dapat dilihat pada Gambar 5 sampai Gambar 7

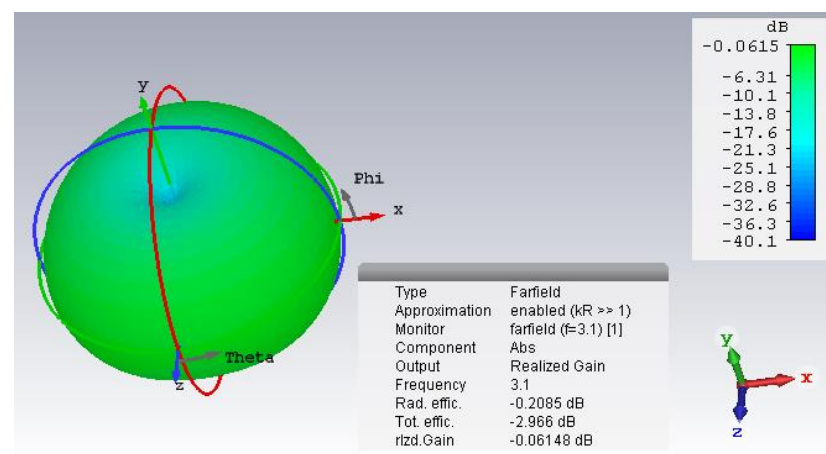

Gambar 5. pola radiasi antena A frekuensi 3,1 GHz.

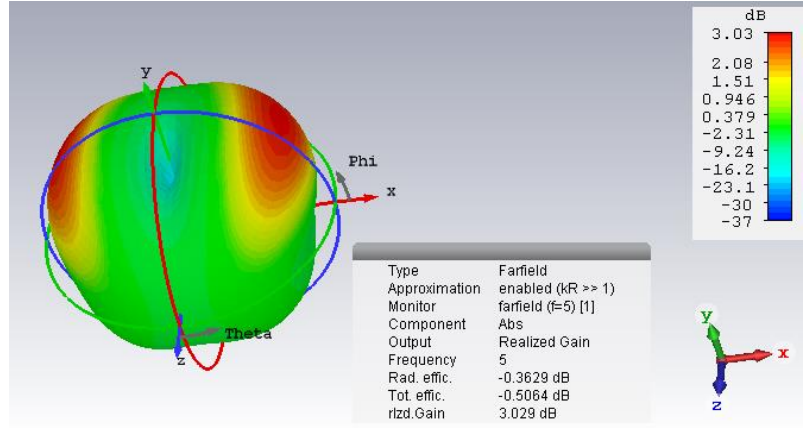

Gambar 6. pola radiasi antena A frekuensi 5 GHz.

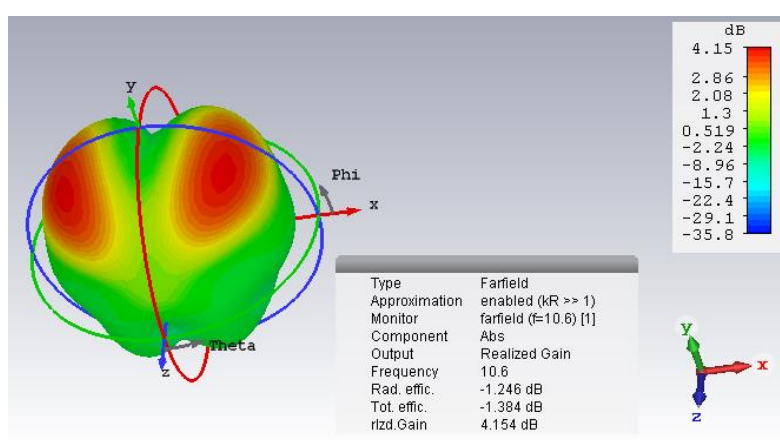

Gambar 7. pola radiasi antena A frekuensi 5 GHz.

Berdasarkan Gambar 5-7, terlihat bahwa nilai gain antena A pada frekuensi $3,1 \mathrm{GHz}$ sebesar $-0,1 \mathrm{~dB}$ dimana nilai gain tersebut belum memenuhi spesifikasi diharapkan yaitu gain $>2 \mathrm{~dB}$. Sedangkan nilai gain antena A pada frekuensi $5 \mathrm{GHz}$ dan $10,6 \mathrm{GHz}$ sudah lebih dari $2 \mathrm{~dB}$.

\subsection{Desain Antena B (Parameter Studi dari Antena} A)

\subsubsection{Desain Characteristic Mode Analys Patch B}

Pada Gambar 8 menampilkan desain patch antena B pada characteristic mode analysis (CMA).

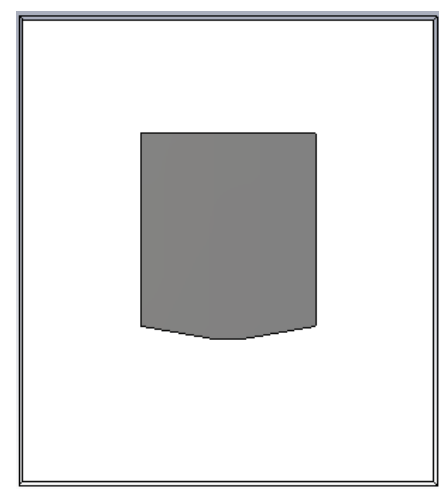

Gambar 8. Desain Patch B dengan CMA 


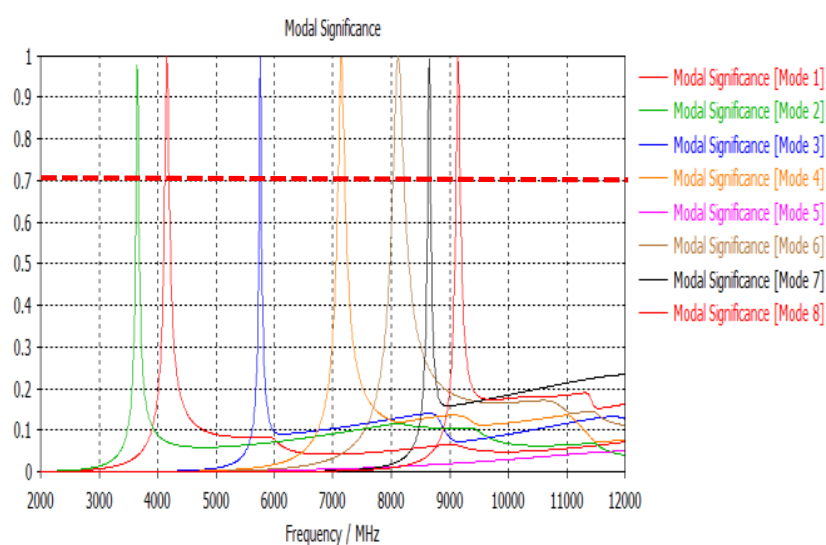

Gambar 9. Grafik Modal Significance patch B

Modal Significance patch B, dari 8 mode yang diaktifkan terdapat 7 mode yang mencapai nilai maksimum. Dari ketujuh mode yang mencapai nilai maksimum sudah beresonansi dan mendominasi radiasi dari frekuensi rendah yaitu 3-4 GHz dan beresonansi pada frekuensi tinggi yaitu 6-10 GHz sehingga sudah dapat berpengaruh untuk frekuensi ultra wideband yaitu 3,1-10,6 GHz.

\subsubsection{Desain Antena B (antena dengan bevel)}

Desain antena B merupakan desain antena yang hasilnya sudah memenuhi spesifikasi. Desain antenna B ditampilkan pada Gambar 10 dan ukuran desain antena B di tunjukkan pada Tabel 2.

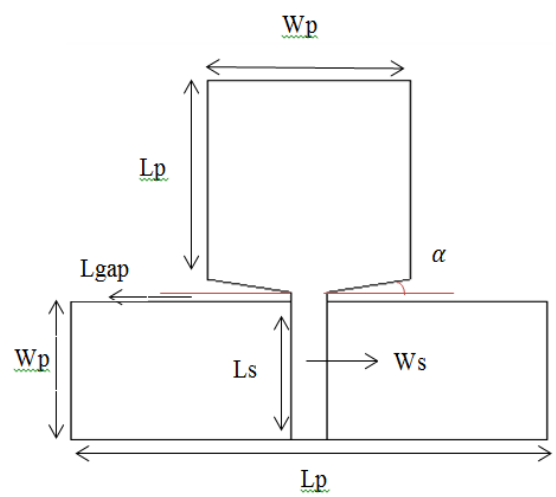

Gambar 10. Desain antenna B untuk komunikasi UWB

Tabel 2. Parameter Akhir Antena Monopol Untuk Komunikasi UWB

\begin{tabular}{lcc}
\hline \multicolumn{1}{c}{ Name } & symbol & Value \\
\hline Lebar patch & Wp & 17 \\
Panjang patch & $\mathrm{Lp}$ & 20 \\
Lebar ground & $\mathrm{Wg}$ & 13 \\
Panjang ground & $\mathrm{Lg}$ & 40 \\
Lebar saluran & Ws & 3 \\
Panjang saluran & $\mathrm{Ls}$ & 13.9 \\
Sudut bevel & $\alpha$ & $5^{\circ}$ \\
\hline
\end{tabular}

\subsection{Hasil Simulasi Antena B 2.7.1. Return Loss}

Hasil return loss antena B dapat ditampilkan pada grafik yang terdapat pada Gambar 11.

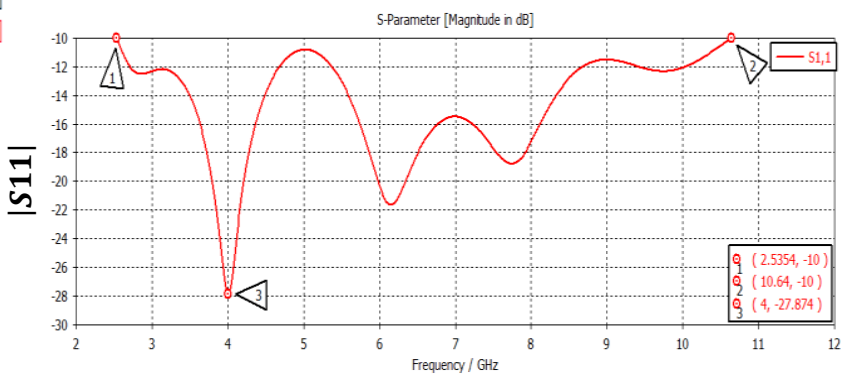

Gambar 11. Grafik Koefisien Refleksi $|S 11|$ Terhadap Frekuensi Hasil Simulasi Antena B

Berdasarkan grafik tersebut, terlihat bahwa frekuensi antena B adalah 2,5-10,6 GHz dimana hasil tersebut sudah memenuhi frekuensi yang diharapkan spesifikasi yaitu $3,1-10,6 \mathrm{GHz}$.

\subsubsection{Gain dan pola radiasi}

Hasil pola radiasi dan gain antena B pada frekuensi 3,1 $\mathrm{GHz}, 5 \mathrm{GHz}$, dan 10,6 GHz dapat dilihat pada Gambar 12 sampai Gambar 14

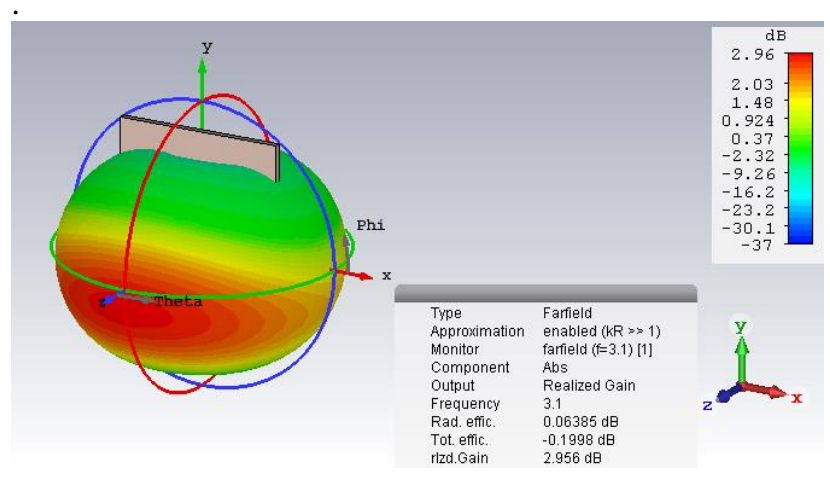

Gambar 12. pola radiasi antena B frekuensi 3,1 GHz.

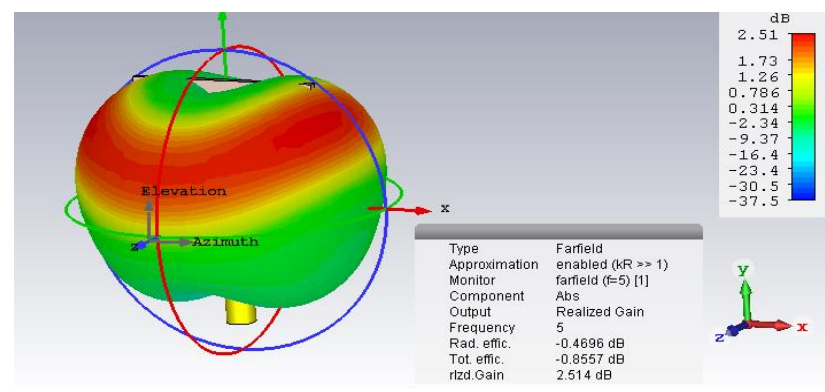

Gambar 13. pola radiasi antena B frekuensi 5 GHz. 


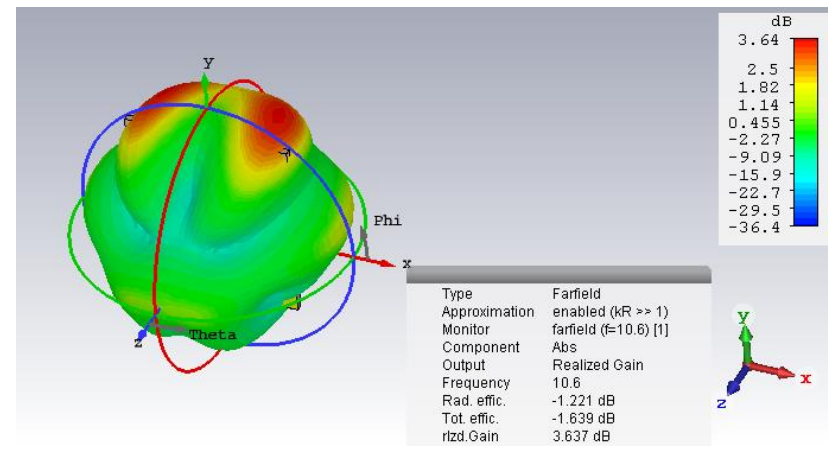

Gambar 14. pola radiasi antena B frekuensi 310,6 GHz.

Dari Gambar 12 sampai Gambar 14 didapat besar gain antena monopol cetak pada frekuensi $3,1 \mathrm{GHz}, 5 \mathrm{GHz}$, dan 10,6 Ghz adalah 2,956 dB, 2,514 dB, dan 3,637 dB. Besar gain lebih besar dari $2 \mathrm{~dB}$ menunjukan gain sudah sesuai spesifikasi.

\section{Hasil dan Analisa}

\subsection{Fabrikasi antena monopol cetak}

Penelitian ini merancang antena monopol cetak yang dapat dilihat pada Gambar 15. Spesifikasi dan dimensi perancangan antena monopol cetak sesuai dengan parameter yang didapatkan dari studi parameter simulasi antena. Perancangan antena menggunakan port SMA female dengan bahan substrat adalah copper yang memiliki konstanta dielektrik 4,3 dan ketebalan substrat $1,6 \mathrm{~mm}$.
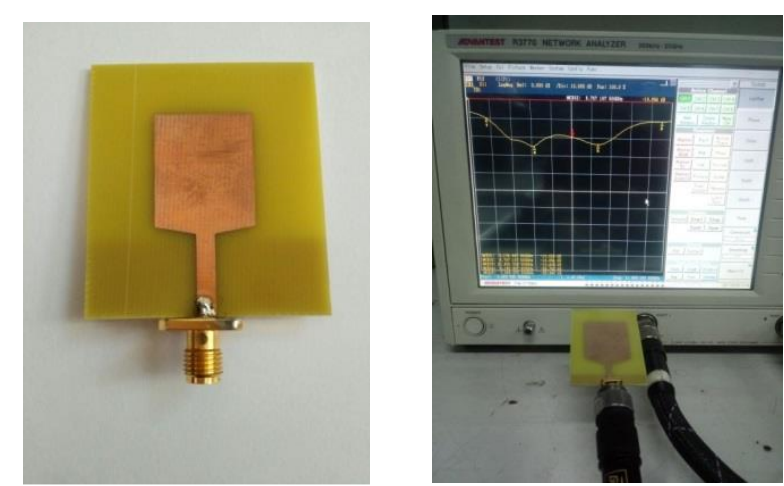

Gambar 15. Hasil Fabrikasi antena monopol cetak desain B.

\subsection{Pengukuran Return Loss}

Pengukuran return loss pada antena menggunakan Advantest R3770 Network Analyzer. Perangkat Vector Network Analyzer dapat menganalisis scattering parameter, return loss dan VSWR. Hasil pengukuran menggunakan adalah berupa grafik frekuensi terhadap waktu sehingga dapat dianalisis lebih dalam. Hasil pengukuran return loss dan VSWR ditampilkan dalam bentuk grafik kurva. Perbandingan return loss simulasi dan pengukuran dapat dilihat pada Gambar 16.

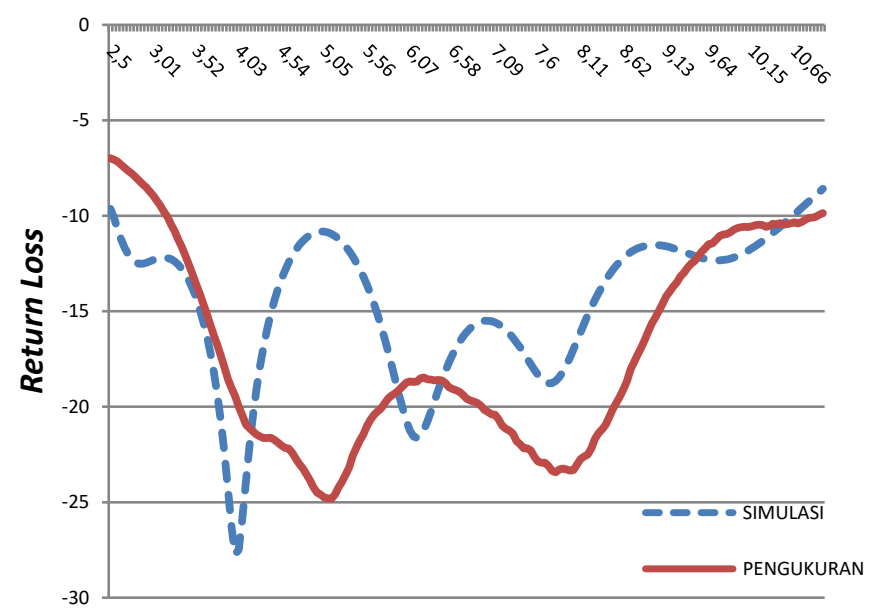

Gambar 16. Grafik perbandingan return loss hasil simulasi dan pengukuran

Tabel 3. Frekuensi pada return loss $=-10 \mathrm{~dB}$ antena monopol Cetak

\begin{tabular}{ccc}
\hline \multirow{2}{*}{ Frekuensi } & \multicolumn{2}{c}{ Nilai Return loss $=-\mathbf{1 0 ~} \mathbf{~ B B}(\mathbf{G H z})$} \\
& Simulasi & Pengukuran \\
\hline Frekuensi Bawah & 2,5425 & 3,18 \\
Frekuensi Atas & 10,6175 & 10,915 \\
\hline
\end{tabular}

\subsection{Pengukuran Pola Radiasi}

Pengukuran pola radiasi dan polarisasi antena yang ideal adalah dilakukan di ruang tanpa gama untuk menghilangkan interferensi dari sinyal lain. Gambar 1722 memperlihatkan perbandingan pola radiasi simulasi dan pengukuran pada frekuensi $3,1 \mathrm{GHz}, 5 \mathrm{GHz}$, dan 10,6 GHz.

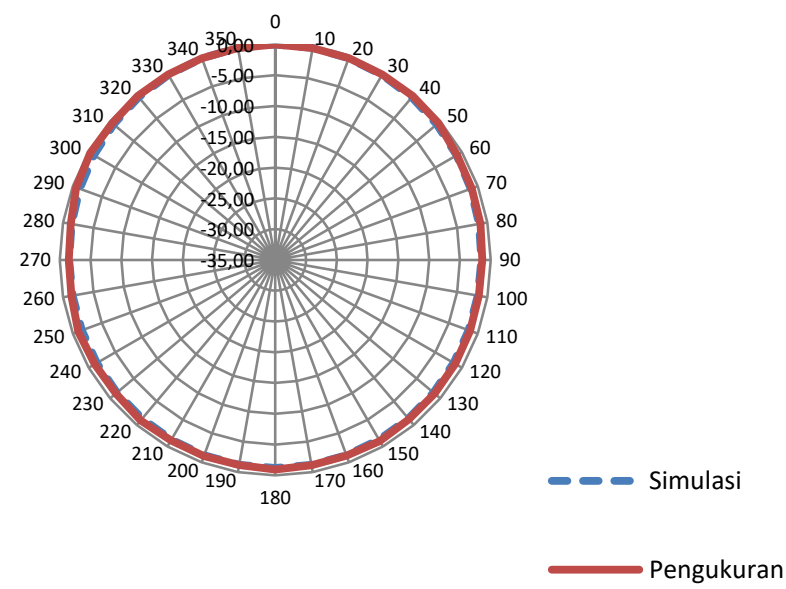

Gambar 17. Perbandingan pola radiasi azimuth antenna monopol cetak $p h i=0^{\circ}$ frekuensi $3,1 \mathrm{GHz}$. 

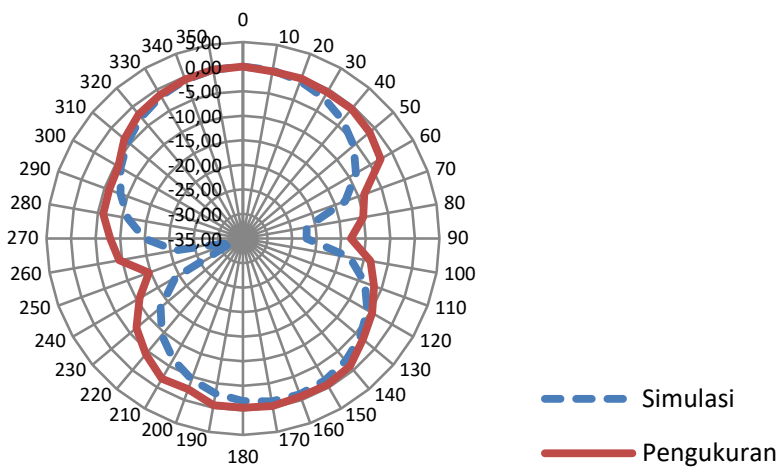

Gambar 18. Perbandingan pola radiasi elevasi antenna monopol cetak $p h i=90^{\circ}$ frekuensi $3,1 \mathrm{GHz}$.
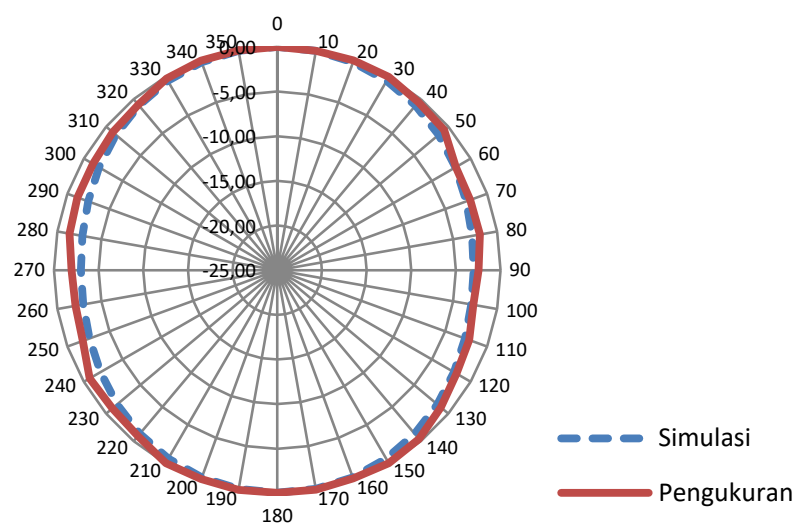

Gambar 19. Perbandingan pola radiasi azimuth antenna monopol cetak $p h i=0^{\circ}$ frekuensi $5 \mathrm{GHz}$.
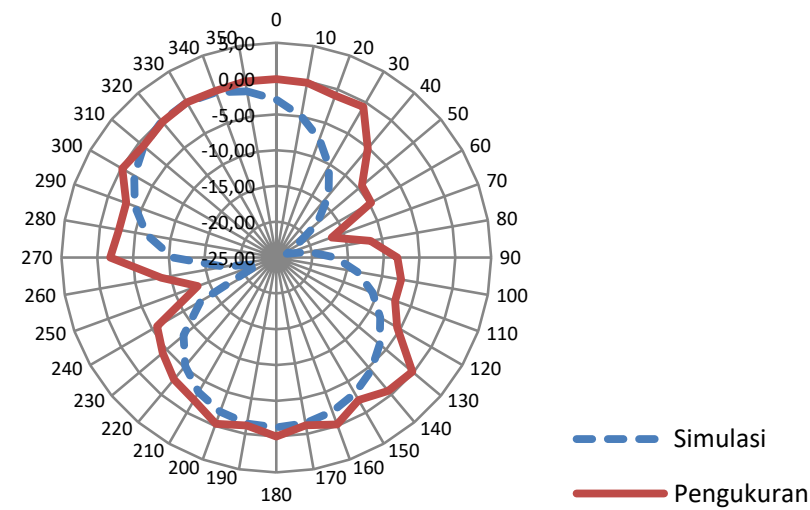

Gambar 20. Perbandingan pola radiasi elevasi antenna monopol cetak $p h i=90^{\circ}$ frekuensi $5 \mathrm{GHz}$.

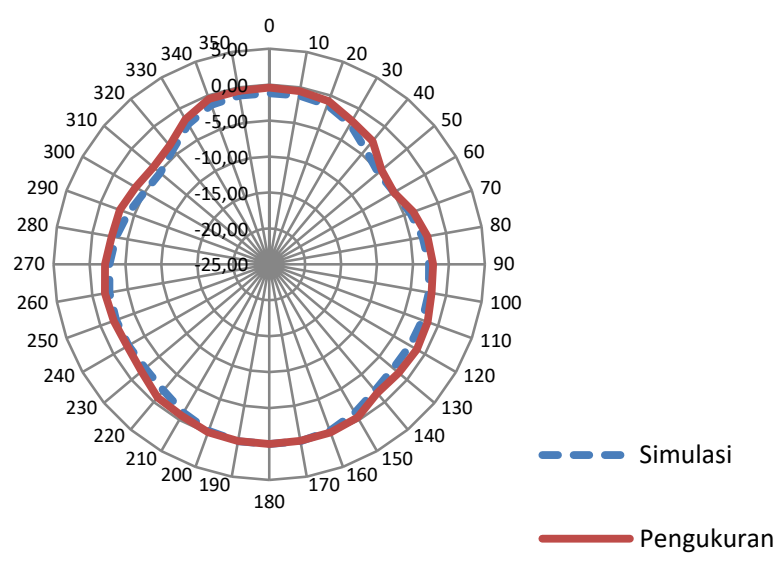

Gambar 21. Perbandingan pola radiasi azimuth antenna monopol cetak $p h i=0^{\circ}$ frekuensi $10,6 \mathrm{GHz}$.

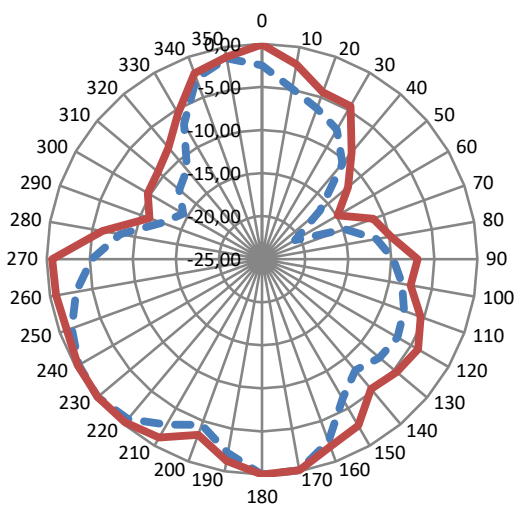

- Simulasi

Pengukuran

Gambar 22. Perbandingan pola radiasi elevasi antenna monopol cetak $p h i=90^{\circ}$ frekuensi $10,6 \mathrm{GHz}$.

Pada Gambar 17 sampai Gambar 22 hasil perbandingan simulasi dengan pengukuran pola radiasi sudah mendekati untuk bidang azimuth dan elevasi. Perbedaan yang terjadi antara simulasi dengan pengukuran disebabkan karena kurang presisinya pembuatan antena, serta pengukurannya masih dilakukan dengan manual (bukan menggunakan mesin). Kuncup utama pola radiasi pengujian terdapat dua nilai daya terima terbesar, hal ini menunjukan bahwa antena monopol cetak mempunyai pola radiasi omnidirectional. 


\subsection{Evaluasi Performansi Antena}

Setelah melakukan pengujian pada semua parameter antena, dilakukan evaluasi hasil untuk membandingkan hasil pengujian dengan spesifikasi yang diinginkan. Hasil perbandingan pengujian ditunjukan pada Tabel 3 .

Tabel 4. Perbandingan hasil pengujian antena dengan spesifikasi antenna monopol cetak

\begin{tabular}{cccc}
\hline Parameter & Spesifikasi & Simulasi & Pengukuran \\
\hline Frekuensi kerja $(\mathrm{GHz})$ & $3,1-10,6$ & $2,5-10,8$ & $3,1-10,9$ \\
return loss & 50 & 50 & 50 \\
$\leq-10 \mathrm{~dB})$ & $\geq 2$ & 2,9 & 3,1 \\
Impedansi $(\mathrm{Ohm})$ & $\geq 2$ & 2,5 & 2,6 \\
Gain $3,1 \mathrm{GHz}(\mathrm{dB})$ & $\geq 2$ & 3,6 & 3,7 \\
Gain $5 \mathrm{GHz}(\mathrm{dB})$ & Omni- & Omnidirectinal \\
Gain 10,6 GHz $(\mathrm{dB})$ & Omidirectinal & directinal & [5] \\
Polaradisi & & &
\end{tabular}

\section{Kesimpulan}

Berdasarkan hasil pengukuran, antena monopol cetak bekerja pada frekuensi ultra wideband 3,1-10,9 $\mathrm{GHz}$ untuk return loss kurang dari $-10 \mathrm{~dB}$ dan VSWR $\leq 2$. Nilai gain antena monopol cetak pada frekuensi $3,1 \mathrm{GHz}$, $5 \mathrm{GHz}$, dan 10,6 Ghz sebesar 2,1 dB, 2,6 dB, dan 3,7 dB. Nilai gain pengukuran sudah mendekati nilai gain pada simulasi hanya selisih 0,1-0,2 dB pada setiap sampel frekuensi yang diuji. Pola radiasi yang dihasilkan adalah omnidirectional. Hasil dari simulasi dan pengukuran sudah sesuai dengan spesifikasi.

\section{Referensi}

[1]. Hans Gregory Schantz, "A Brief History of UWB Antennas," The Proceedings of The 2003 IEEE UWBST Conference, 2013.

[2]. Qi Wu, Ronghong Jin, Junping Geng, and Min Ding, "Printed Omni-Directional UWB Monopole Antenna With Very Compact Size," IEEE Transactions on Antennas and Propagation, Vol. 56, No. 3, 2008.

[3]. Seong-Youp Suh, Warren L. Stutzman, and William A. Davis, "A New Ultrawideband Printed Monopole Antenna: The Planar Inverted Cone Antenna (PICA)," IEEE Transactions on Antennas and Propagation, Vol. 52, No. 5, 2004.

[4]. Aaron J. Kerkhoff, Robert L. Rogers, and Hao Ling, "Design and Analysis of Planar Monopole Antennas Using a Genetic Algorithm Approach," IEEE Transactions on Antennas and Propagation, Vol. 52, No. 10, 2004.

[5]. John D. Kraus, Antennas, 2nd Ed. New Delhi : McgrawHill Companies, 2001.

[6]. C. A. Balanis, Antenna Theory, 3rd Ed. New Jersey: John Wiley \& Sons, 2005.

[7]. Y. Lu, Y. Huang, H.T. Chattha, and Y. Shen, "Technique for Minimising the Effects of Ground Plane on Planar Ultra-Wideband Monopole Antennas," IET Microwaves, Antennas \& Propagation, 2011.

[8]. Marta Cabedo-Fabres, Eva Antonino-Daviu, Alejandro Valero Nogueira and Miguel Ferrando Bataller, "The Theory Of Characteristic Modes Revisited: A Contribution To The Design Of Antennas For Modern Applications," IEEE Antennas And Propagation Magazine, Vol. 49, No. 5, 2007.

[9]. R. Harrington and J. Mautz, "Theory of characteristic modes for condcting bodies," IEEE Transactions on Antennas and Propagation, vol. 19, no. 5, pp. 622-628, Sep. 1971.

[10]. John D. Kraus, Antennas, 2nd Ed. New Delhi : McgrawHill Companies, 2001. 